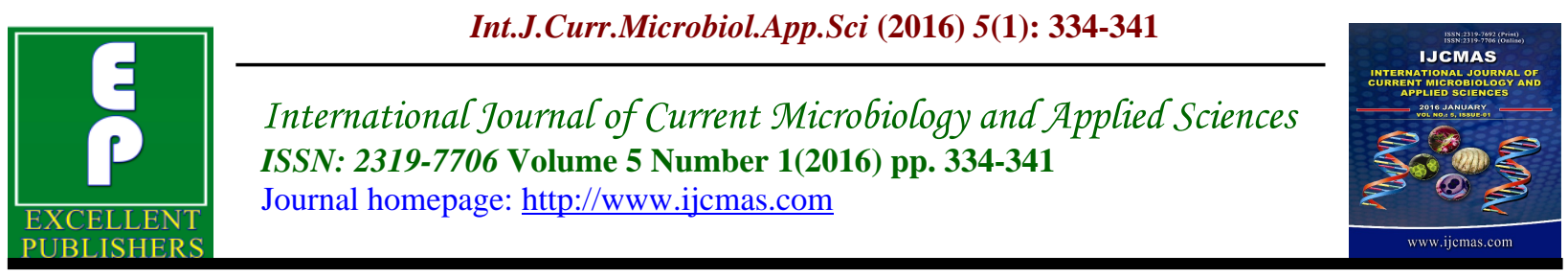

Original Research Article

hittp://dx.doi.org/10.20546/ijcmas.2016.501.03ii

\title{
Determination of Minimum Inhibitory Concentration (MIC) of Routinely used Disinfectants against Microflora Isolated from Clean Rooms
}

\author{
Subhash Chand*, Kallol Saha, Prakash Kumar Singh, Smriti Sri and Neeraj Malik \\ National Institute of Biologicals (NIB), Ministry of Health \& Family Welfare, \\ Govt. of India, Noida, India \\ *Corresponding author
}

\begin{abstract}
A B S T R A C T
Keywords

Clean Room,

Phenol

Coefficient,

Rideal Walker

Coefficient

(RWC),

MIC, MBC

Article Info

Accepted:

16 December 2015

Available Online:

10 January 2016

The predominant microbial strains distributed in the clean rooms of sterility test facility at NIB were screened and minimum inhibitory concentration (MIC) and Minimum Bactericidal Concentration (MBC) of routinely used disinfectants coded as $\mathrm{A}, \mathrm{B}, \mathrm{C}, \mathrm{D}$ against the isolated microbial strains were determined by broth dilution method. Routinely used test disinfectants were standardized by Rideal Walker Co-efficient (RWC) method using phenol as a standard disinfectant. Nine isolates (IN/01 to IN/09) were isolated which closely resemble to genera Staphylococcus, Micrococcus, Bacillus, Penicillium and Aspergillus in their morphological and biochemical characteristics. RWC of disinfectant A was found higher than all other disinfectants used in the study, however the disinfectant B was found effective even at a very low concentration of $0.025 \times 10^{4} \mu \mathrm{g} / \mathrm{ml}$ against the isolated microbial strains in MIC study. Bacteria widely distributed in clean room were mainly gram positive strains. Isolates belong to the spore forming genera i.e. Bacillus, Penicillium and Aspergillus were highly resistant to the $1 \%$ disinfectant, while rest of the isolates were sensitive to all the disinfectants used in the study. Staphylococcus strains were the most sensitive followed by Micrococcus strain.
\end{abstract}

\section{Introduction}

Clean room is an enclosed space in which airborne particulates, contaminants, and pollutants are kept within strict limits. Clean rooms are essential in Regulatory Quality Control laboratories, aseptic pharmaceutical and biotech production units. Humans are considered as the main source of contamination in classified areas due to constant endogenous emissions and the operator who carries out aseptic procedures must be continuously observed and evaluated and must be aware of conduct procedure. Microbiological monitoring of the Clean rooms and identifying the predominant isolates is a part of good manufacturing practices (Akers, 1997).

According to WHO recommended limits for micro-organisms during operation, the permissible limit of colony forming unit 
(cfu) on air sample for grade A and B is <1 and 10 respectively (Geneva, 1999).To meet such requirements, all the surfaces within the clean room, air, walls, floors and personnel hands should be disinfected with a variety of disinfectants.

Maintaining the integrity of a clean room is always a challenging task and to decide which method to be employed in disinfecting aseptic activity, we need to understand the kind of bacteria that are the prime source of contamination (Nagarkar et al., 2001). Therefore, assessment of microbial diversity of clean rooms as well as their resistant characteristics is essential to the development of disinfectant technologies. So, efficacy of the disinfectants needs to be evaluated.

Passive and active air sampling methods of microbiological monitoring can provide air evaluation for viable particles. In passive air sampling, the environment is monitored by determining the number of microorganisms that settle a culture plate by gravity (Luxemburg, 1998). In active air sampling, microbes can be quantify by air sample volume.

The Rideal Walker Coefficient (RWC) is a figure expressing the disinfecting power of any disinfectant. It is the ratio of the dilution of the disinfectant that kills a microorganism to the dilution of phenol that kills the organism in the same time under identical conditions. The Rideal-Walker coefficient determines the phenol coefficient utilizing the method described by English chemists Samuel Rideal and J. T. Ainslie Walker (Ridealand Walker, 1913). The objective of this study was to isolate and characterize the predominant bacterial and fungal strains distributed in the clean rooms designated for sterility testing of biologicals and suggest MIC of commonly available disinfectants against isolated microbial strains which will help in designing an effective cleaning and disinfection program for clean rooms.

\section{Materials and Methods}

\section{Dehydrated Culture Medium and Chemicals}

Dehydrated media (Nutrient Broth, Nutrient Agar, Soyabean Casein Digest Agar, Saboraud Dextrose Agar) used were of microbiological grade and were of make Oxoid Ltd. The four disinfectants used in the study were coded as A, B, C, D and their composition was given in Table-1.

\section{Isolation of Bacterial and Fungal Strains}

Bacterial and fungal strains were isolated by routine microbiological monitoring of the clean rooms of centralized facility for sterility testing at NIB. The sampling locations were laminar air flow hood, work bench in the Sterility Testing Area, Anteroom, Dressing Room. In active air sampling, by slit-to-agar microbiological air sampler (Mas-100, Manufacturer-2), one thousand litres of the air was drawn at a constant flow of 100 litres/min. In passive air sampling, soyabean casein digest agar (SCDA) or tryptone soya agar (TSA) petriplates (90 $\mathrm{mm}$ diameter) were exposed for 2 hours. SCDA petriplates were incubated for $20-25^{\circ} \mathrm{C}$ and $30-35^{\circ} \mathrm{C}$ for 72 hrs and $48 \mathrm{hrs}$ respectively (USP 36 $<1116>$ ). After appropriate incubation, colonies enumerated on the petriplates were counted on each plate and recorded. Further, isolated strains were purified by streaking method.

\section{Morphological and Biochemical Characterization of Predominant Bacterial and Fungal Strains}

Identification of Bacteria were performed by traditional methods to study the phenotypic 
characteristics including gram staining, morphology, culture characteristics and biochemical reactions. The cell morphology were studied under Trinocular Upright Microscope (Type104C, Nikon) and several biochemical characteristics such as indole, methyl red, voges-proskauer, citrate, catalase, oxidase, starch hydrolysis, sugar fermentation, triple sugar iron agar, urease, gelatin liquification, nitrate reduction were performed (John et al. 1994). The fungal genera were identified by colony characteristics and $20 \%$ lacto-phenol cotton blue (LCB) staining characteristics (Leck, 1999).

\section{Determination of Rideal Walker Co- efficient (RWC)}

Disinfectants A, B, C and D were first standardised by Rideal Walker Coefficient method prior to the determination of MICs against the isolated bacterial strains. Test organism used was Salmonella typhi(NCTC 786)lyophilised culture was obtained from Central Research Institute, Kasauli, Himachal Pradesh. This culture was maintained by subculture on a nutrient agar, incubated the subculture for 24 hours at 37 ${ }^{\circ} \mathrm{C}$ and then stored in refrigerator at a temperature below $22{ }^{\circ} \mathrm{C}$. For this study, a little growth from the most recent subculture in nutrient agar slope was placed in tube of R.W. Broth and incubated for 23 hours at 38 ${ }^{\circ} \mathrm{C}$. A Standard loopful was then transferred to a second tube and incubated as before. This was done at least three times before a test was carried out (Rideal and Walker, 1903, 1913; Drugs and Cosmetics Act, 1940).

Stock solution of standard phenol (as standard) as well as disinfectants (test sample) were prepared in sterile distilled water. Suitable dilutions in sterile distilled water were then immediately prepared from the stock solution. The procedure followed for Rideal Walker Co-efficient was as per the Schedule ' $\mathrm{O}$ ' of Drugs and Cosmetics Act 1940.

\section{Standardisation of Bacterial Suspension}

A loopful culture was transferred from all isolated bacterial strains from nutrient agar slants into $10 \mathrm{ml}$ nutrient broth and incubated at $37^{\circ} \mathrm{C}$ for $20-24$ hour. Tenfold serial dilution were carried out in normal saline. $0.1 \mathrm{ml}$ from each dilution was plated onto the nutrient agar petriplates and spreaded uniformly and incubated at $37^{\circ} \mathrm{C}$ for 24 hours and the number of $\mathrm{cfu} / \mathrm{ml}$ were calculated from the number of colonies formed multiplied by the dilution factor (Sanders, 2012; Li at al., 1996; Madigan et al., 1997).

\section{Determination of MIC and MBC}

MIC and MBC determined by using twofold broth dilution method (Tavares et al. 1997).In this study, two fold serial dilutions of disinfectants were prepared in tubes containing nutrient broth medium and $\geq$ $10^{6} \mathrm{cfu} / \mathrm{ml}$ bacterial cells were inoculated. A comparison of MIC of disinfectants against isolated bacterial strainsand the reference strain of Staphylococcus aureus, MTCC 737 (IMTECH Chandigarh) was also done.

An inoculum of $1 \mathrm{ml}$ of each bacterial strains were inoculated into each dilution tubes and incubated for 48 hours at $30-35^{\circ} \mathrm{C}$. After incubation, the MIC was identified as the lowest concentration of the chemical agent, which resulted in the confirmed inhibition of the growth of tested micro-organisms. The tubes which resulted in the inhibition of the growth were then sub cultured onto nutrient agar and examined for bacterial growth to give minimum bactericidal concentration. 


\section{Results and Discussion}

\section{Morphological Characteristics}

A total of 09 microbial strains (07 bacterial and 02 fungal genera) were isolated in the routine microbiological monitoring of clean rooms of centralized facility for sterility testing. The isolates were identified by a code i.e. IN/01 to IN/09. The colony characteristics of isolates were: IN/01Regular, opaque, smooth, pin head colonies, dull white, flat and butyrous; IN/02 Regular, flat, glistering, yellow, butyrous, small size $1 \mathrm{~mm}$ in diameter; IN/03- Regular, opaque, glistering, mucoidal, orange coloured, $2 \mathrm{~mm}$ in diameter; IN/04- Regular, opaque, flat, yellow, $2 \mathrm{~mm}$ in diameter; IN/05- Irregular, umbonate, rhizoidal, ruff, dull white coloured, brittle $4 \mathrm{~mm}$ in diameter; IN/06- Irregular, umbonate, filamentous, viscous, ruff, dull white coloured, $4 \mathrm{~mm}$ in diameter; IN/07Irregular, umbonate, undulate, ruff, opaque, dull white coloured, $4 \mathrm{~mm}$ in diameter; IN/08- Initially white cottonish growth changes to blackish after 4-5 days and reverse is brown coloured; IN/09- White cottonish and puffy colonies. Reverse is yellow coloured.

\section{Staining and Biochemical Characteristics}

Gram staining showed that all isolated bacterial strains were gram positive. The staining and biochemical characteristics of bacterial isolates were tabulated in Table 2 . LCB staining of isolate no. IN/08 had shown septate hyaline hyphae, branched conidiophore, metulae, philades and conidia were observed. The metulae carry the flask shaped philades. The philades form brushlike clusters which are also referred as "penicillin". Conidia are round, unbranching chains at the tips of the philades. LCB staining of isolate no. IN/09 had shown columnar, uniseriate conidial heads. Conical vesicles support a single row of philades on the upper $2 / 3^{\text {rd }}$ of the vesicles, conidia are produced in long chains.

The morphology and biochemical characteristics of the isolates IN/01 to IN/03 closely resembles to the genus Staphylococcus, IN/04 closely resembles to genus Micrococcus and IN/05 to IN/07 closely resembles to genus Bacillus. IN/08 and IN/09 closely resembles to genus Penicillium and Aspergillus respectively.

\section{Rideal Walker Co-efficient (RWC) of Disinfectants}

RWC of disinfectant Awas found higher than all other disinfectants used in the study. RWC of disinfectant A, B, C and D were 5.21, 3.6, 0.05 and 0.05 respectively. RWC of disinfectants were graphically represented in Figure 1.

\section{MIC and MBC of Disinfectants}

MIC of disinfectant A against Staphylococcus aureus MTCC 737, Staphylococcus strain IN/01, IN/02, IN/03 and Micrococcus strain IN/04 were 0.125 $\mathrm{x} 10^{4}, 0.0625 \mathrm{x} 10^{4} \mu \mathrm{g} / \mathrm{ml}, 0.125 \times 10^{4} \mu \mathrm{g} / \mathrm{ml}$, $0.0625 \times 10^{4}$ and $0.125 \times 10^{4}$ respectively.MIC of disinfectant B against Staphylococcus aureus MTCC 737, Staphylococcus strain IN/01, IN/02, IN/03 and Micrococcus strain IN/04 were $0.05 \times 10^{4}, 0.025 \times 10^{4} \mu \mathrm{g} / \mathrm{ml}$, $0.025 \times 10^{4} \mu \mathrm{g} / \mathrm{ml}, 0.025 \times 10^{4}$ and $0.05 \times 10^{4}$ respectively.

MIC of disinfectant B against Staphylococcus aureus MTCC 737, Staphylococcus strain IN/01, IN/02, IN/03 and Micrococcus strain IN $/ 0^{4}$ were $0.05 \mathrm{x}$ $10^{4}, 0.025 \times 10^{4} \mu \mathrm{g} / \mathrm{ml}, 0.025 \times 10^{4} \mu \mathrm{g} / \mathrm{ml}$, $0.025 \times 10^{4}$ and $0.05 \times 10^{4}$ respectively. 
Table.1 Composition and Manufacturer of Disinfectants Coded as A, B, C and D

\begin{tabular}{|c|l|l|}
\hline Code & \multicolumn{1}{|c|}{ Composition of Disinfectant (V/V) } & \multicolumn{1}{|c|}{ Manufacturer } \\
\hline A & $\begin{array}{l}\text { Chloroxylenol : 4.8\%w/v } \\
\text { Terpinol : } 90 \% \\
\text { Alcohol absolute (denatured): 13.1\% }\end{array}$ & Manufacturer-1 \\
\hline B & $\begin{array}{l}\text { Ethanol: 1-3\% } \\
\text { Isopropyl alcohol : 1-2\% } \\
\text { p-Chloro-o-benzylphenol: 5-6\% } \\
\text { Potassium hydroxide: 3-4\%. } \\
\text { Alkyl (C12-C18) dimethylbenzylammonium chloride: } 0.08 \% \\
\text { Alkyl (C12-C16) dimethylbenzylammonium chloride: } 0.02 \%\end{array}$ & \\
\hline C & Isopropyl alcohol(99.5\%) & Manufacturer-1 \\
\hline D & Ethanol (99.9\%) & Manufacturer-2 \\
\hline & & Manufacturer-2 \\
\hline
\end{tabular}

Table.2 Staining and Biochemical Characteristics of Bacterial Isolates

\begin{tabular}{|l|l|l|l|l|l|l|l|l|}
\hline \multirow{2}{*}{ S.N. } & \multirow{2}{*}{ Test } & \multicolumn{2}{l}{ Characteristics of isolates } \\
\cline { 2 - 9 } & & IN/01 & IN/02 & IN/03 & IN/04 & IN/05 & IN/06 & IN/07 \\
\hline 1 & Gram Reaction & + & + & + & + & + & + & + \\
\hline 2 & Motility & - & - & - & - & + & + & + \\
\hline 3 & Starch Hydrolysis & ND & ND & ND & ND & + & + & + \\
\hline 4 & Growth in 6.5\% NaCl & + & + & + & + & + & + & + \\
\hline 5 & $\begin{array}{l}\text { Growth in Nutrient Broth } \\
\text { (pH 9.6) }\end{array}$ & + & - & + & ND & ND & ND & ND \\
\hline 6 & Growth at 45 ${ }^{\circ}$ C & - & - & - & ND & ND & ND & ND \\
\hline 7 & Catalase & + & + & + & + & + & - & + \\
\hline 8 & Coagulase & - & - & - & - & ND & ND & ND \\
\hline 9 & Oxidase & - & - & - & + & - & - & - \\
\hline 10 & Indole & - & - & - & - & - & - & - \\
\hline 11 & Methyl Red & - & - & - & - & + & + & - \\
\hline 12 & Voges Proskauer & - & - & - & + & - & - & - \\
\hline 13 & Citrate & - & - & - & + & + & - & + \\
\hline 14 & Glucose Fermentation & A & A & AG & A & A & A & A \\
\hline 15 & Fructose Fermentation & - & A & AG & A & - & A & - \\
\hline 16 & Sucrose Fermentation & A & A & AG & A & A & A & A \\
\hline 17 & Mannitol Fermentation & - & - & - & - & A & A & A \\
\hline 18 & Mannose Fermentation & A & A & AG & A & A & A & A \\
\hline 19 & Sorbitol Fermentation & A & - & - & - & A & A & - \\
\hline 20 & TSI & A/ A & A/ A & A/ A & A/ AL & AL/A & A/ AL & AL/A \\
\hline 21 & Gelatin Liquification & - & - & - & + & + & - & + \\
\hline 22 & Nitrate Reduction & - & + & - & + & - & + & - \\
\hline 23 & Urease & + & - & - & + & + & + & - \\
\hline 24 & Antibiotic Activity & ND & ND & ND & ND & ND & ND & + \\
\hline 25 & $\begin{array}{l}\text { Characteristics } \\
\text { resembles to genus }\end{array}$ & $\begin{array}{l}\text { Staphy- } \\
\text { lococcus }\end{array}$ & $\begin{array}{l}\text { Staphy- } \\
\text { lococcus }\end{array}$ & $\begin{array}{l}\text { Staphy- } \\
\text { lococcus }\end{array}$ & $\begin{array}{l}\text { Micro- } \\
\text { coccus }\end{array}$ & Bacillus & Bacillus & Bacillus \\
\hline
\end{tabular}

"+ : positive; -: negative; ND: not determined; A: acid; AL: alkaline; AG: acid and gas; TSI: triple sugar iron agar 
Table.3 The MICs and MBCs of Disinfectants Determined against the Isolates IN/01, IN/02, IN/03, IN/04 and Staphylococcus aureus MTCC 737

\begin{tabular}{|c|c|c|c|c|c|}
\hline S. $\mathbf{N}$. & $\begin{array}{l}\text { Classified } \\
\text { Environmental } \\
\text { Isolates }\end{array}$ & $\begin{array}{l}\text { Inoculum } \\
(\mathrm{cfu} / \mathrm{ml})\end{array}$ & Disinfectants & MIC $(\mu \mathrm{g} / \mathrm{ml})$ & $\begin{array}{l}\text { MBC } \\
(\mu \mathrm{g} / \mathrm{ml})\end{array}$ \\
\hline \multirow{4}{*}{1.} & \multirow{4}{*}{$\begin{array}{l}\text { Staphylococcus } \\
\text { aureus } \\
\text { MTCC } 737 \\
\text { (Standard) }\end{array}$} & \multirow{4}{*}{$8 \times 10^{6}$} & $\mathrm{~A}$ & $0.125 \times 10^{4}$ & $0.25 \times 10^{4}$ \\
\hline & & & B & $0.05 \times 10^{4}$ & $0.1 \times 10^{4}$ \\
\hline & & & $\mathrm{C}$ & $6.25 \times 10^{4}$ & $12.5 \times 10^{4}$ \\
\hline & & & $\mathrm{D}$ & $6.25 \times 10^{4}$ & $12.5 \times 10^{4}$ \\
\hline \multirow{4}{*}{2} & \multirow{4}{*}{$\begin{array}{l}\text { Staphylococcus } \\
\text { strain } \\
\text { (Isolate No. IN/01) }\end{array}$} & \multirow{4}{*}{$14 \times 10^{6}$} & $\mathrm{~A}$ & $0.0625 \times 10^{4}$ & $0.125 \times 10^{4}$ \\
\hline & & & B & $0.025 \times 10^{4}$ & $0.05 \times 10^{4}$ \\
\hline & & & $\mathrm{C}$ & $3.125 \times 10^{4}$ & $6.25 \times 10^{4}$ \\
\hline & & & $\mathrm{D}$ & $3.125 \times 10^{4}$ & $6.25 \times 10^{4}$ \\
\hline \multirow{4}{*}{3} & \multirow{4}{*}{$\begin{array}{l}\text { Staphylococcus } \\
\text { strain } \\
\text { (Isolate No. IN/02) }\end{array}$} & \multirow{4}{*}{$9 \times 10^{6}$} & A & $0.125 \times 10^{4}$ & $0.25 \times 10^{4}$ \\
\hline & & & B & $0.025 \times 10^{4}$ & $0.05 \times 10^{4}$ \\
\hline & & & $\mathrm{C}$ & $6.25 \times 10^{4}$ & $12.5 \times 10^{4}$ \\
\hline & & & $\mathrm{D}$ & $3.125 \times 10^{4}$ & $6.25 \times 10^{4}$ \\
\hline \multirow{4}{*}{4} & \multirow{4}{*}{$\begin{array}{l}\text { Staphylococcus } \\
\text { strain } \\
\text { (Isolate No. IN/03) }\end{array}$} & \multirow{4}{*}{$11 \times 10^{6}$} & $\mathrm{~A}$ & $0.0625 \times 10^{4}$ & $0.125 \times 10^{4}$ \\
\hline & & & $\mathrm{B}$ & $0.025 \times 10^{4}$ & $0.05 \times 10^{4}$ \\
\hline & & & $\mathrm{C}$ & $3.125 \times 10^{4}$ & $6.25 \times 10^{4}$ \\
\hline & & & $\mathrm{D}$ & $3.125 \times 10^{4}$ & $6.25 \times 10^{4}$ \\
\hline \multirow{4}{*}{5} & \multirow{4}{*}{$\begin{array}{l}\text { Micrococcus strain } \\
\text { (Isolate No. IN/04) }\end{array}$} & \multirow{4}{*}{$2 \times 10^{6}$} & $\mathrm{~A}$ & $0.125 \times 10^{4}$ & $0.25 \times 10^{4}$ \\
\hline & & & B & $0.05 \times 10^{4}$ & $0.1 \times 10^{4}$ \\
\hline & & & $\mathrm{C}$ & $6.25 \times 10^{4}$ & $12.5 \times 10^{4}$ \\
\hline & & & $\mathrm{D}$ & $12.5 \times 10^{4}$ & $25 \times 10^{4}$ \\
\hline
\end{tabular}

Figure.1 Rideal Walker Coefficient (R.W.C.) or Phenol Coefficient of Disinfectants

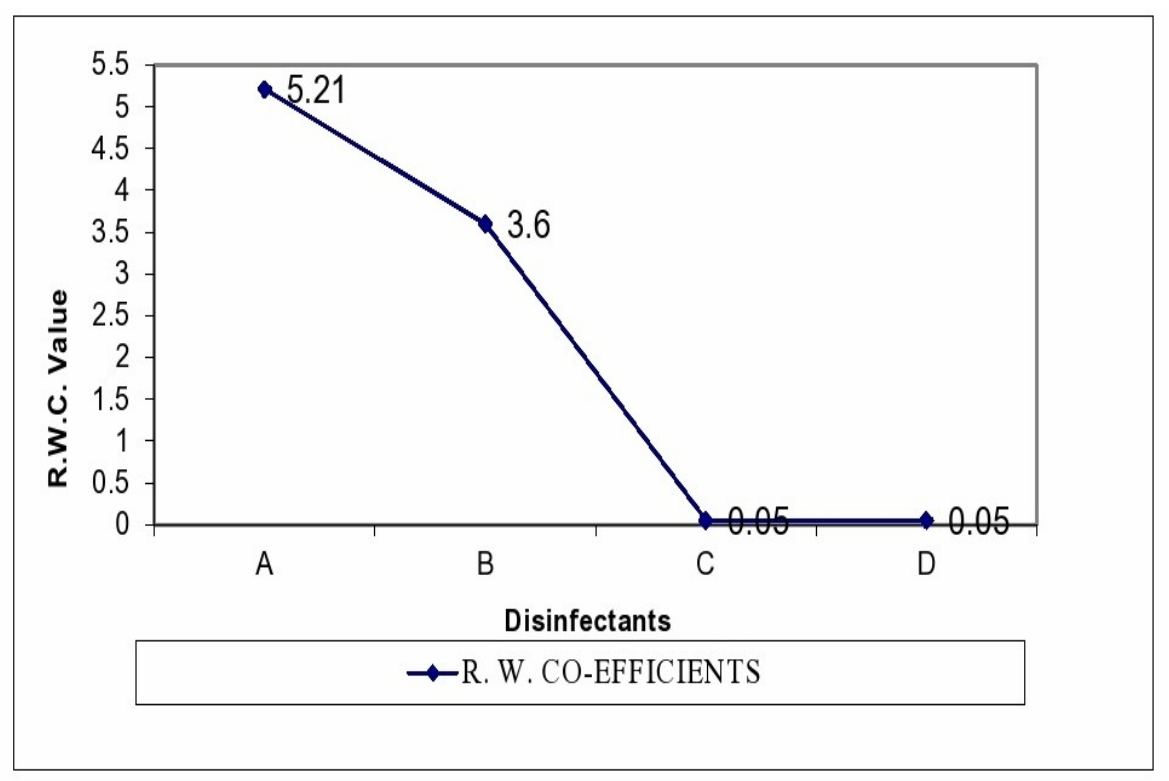


MIC of disinfectant D against Staphylococcus aureus MTCC 737, Staphylococcus strain IN/01, IN/02, IN/03 and Micrococcus strain IN/04 were 6.25 $\mathrm{x} 10^{4}, 3.125 \times 10^{4} \mu \mathrm{g} / \mathrm{ml}, 3.125 \times 10^{4} \mu \mathrm{g} / \mathrm{ml}$, $3.125 \times 10^{4}$ and $\quad 12.5 \times 10^{4}$ respectively. However, MIC study of disinfectants against the Bacillus stains (isolates no. IN/05, IN/06 and IN/07) were found to be resistant to even $1 \%$ disinfectants used in the study. The MICs and MBCs of disinfectants determined against the isolates IN/01, IN/02, IN/03, IN/04 and Staphylococcus aureus MTCC 737 were tabulated in Table 3.

Bacterial strains isolated in the clean room were gram positive bacteria, either sporeforming Bacillus, which is known to confer resistance to extreme environmental conditions or coagulase-negative staphylococci (CNS), which is opportunistic bacteria and undoubtedly are able to cause severe infections in humans. MIC determined against the isolates showed that lowest concentration of disinfectant B is most effective than all other disinfectants against the bacterial isolates except Bacillus strains.

The $1 \%$ disinfectant $\mathrm{A}$ which in tubes mask the visualization of microbial growth in broth tubes used in tube dilution method for MIC, which is limit of tube dilution method. For most disinfectants, the studies are largely on phenomenological descriptions of the occurrence. There is little information available about the frequency with which resistance develops and the impact of environmental factors on resistance development (Chapman, 2003). Further work needs to be done on DNA analysis of isolated bacterial and fungal strains that are resistant to certain disinfectants and to investigate the efficiency of DNA damaging on bacteria by disinfectants.
Environment Monitoring serves as an important tool for Quality Assurance programs. Active and Passive air sampling can provide air evaluation for viable particles. There are mainly three prime source of contamination. The first source is humans errors, so hands must be washed with proper disinfectant. Secondly, the room surface, wall, ceiling also contributes to contamination. Proper cleaning of room surface, wall and ceiling must be done with efficient disinfectant. To ensure a clean room conforming to the designated classification, constant monitoring of contaminant sources and identification of the predominant contaminant bacteria is usually necessary. This study will help in the elimination of microbial isolates from clean rooms by identifying them, studying their resistance and sensitivity pattern against different disinfectants used for routine disinfection of laboratory area and thus will reduce the chances of product contamination resulting false positive in sterility test.

\section{Acknowledgment}

This research paper is dedicated to Late Sh. Ashwani K. Sahu, Former Head,Centralised Facility for sterility test, National Institute of Biological (Ministry of Health \& Family Welfare, Govt. of India) Noida, who had initiated this research work but unfortunately passed away due to sudden cardiac arrest. Authors would like to thank Dr. G.R. Soni, DD(QC) for his guidance and Dr. Surinder Singh, Director, NIB for continuous support and encouragement. There is no Conflict of Interest shown by the authors. Study is fully funded by NIB.

\section{References}

Akers, J.E. 1997. Environmental monitoring and control: proposed standards, current practices and future 
directions. PDA J. Pharm. Sci. Technology.51(1): 36-47.

Chapman, J.S. 2003. Disinfectant resistance mechanisms, cross-resistance and coresistance. Int. Biodeter. Biodegr. 51(4):271-276.

Cruickshank, R., Duguid, J.P., Marmion, B.P. and Swain, R.H.A. 1982. Medical Microbiology. $12^{\text {th }}$ ed. Vol. II. New York, Churchill Livingstone. pp. 190-193.

Geneva, International Organization for Standardization. 1999. Clean rooms and associated controlled environments.ISO 14644.

Govt. of India. Drugs and Cosmetics Act.1940. Schedule-O. pp. 542-46.

John, G.H., Noel, R.K., Peter, H.A.S. and Bergey, D. 1994. Bergey's Manual of Determinative Bacteriology, 9th Ed, Williams \& Wilkins, Lippincott.

Leck, A. 1999. Preparation of Lactophenol Cotton Blue Slide Mounts. Community Eye Health. 12(30):24.

Li, R.C., Lee, S.W. and Lam, J. S. 1996. Novel method for assessing postantibiotic effect by using the Coulter counter. Antimicrobial Agents Chemotherapy. 40:1751-53.

Luxemburg, Office for Official Publications of the European Communities. 1998. Good manufacturing practices Medicinal products for human and veterinary use. Vol. 4.

Madigan, M.T., Martinko, J.M., Parker, J. and Brock, T.D. 1997 Brock biology of microorganisms. $8^{\text {th }} \mathrm{ed}$, London: Prentice Hall International.
Nagarkar, P.P., Ravetkar, S.D. and Watve, M.G. 2001. Oligophilic bacteria as tools to monitor aseptic pharmaceutical production units. Appl. Environ. Microbiology. 67(3):1371-1374.

Rideal, S. and Walker J.T.A. 1913. Approved Technique of the RidealWalker Test. American Journal of Public Health. 3(6):575-581. [doi: 10.2105/AJPH.3.6.575].

Rideal, S. and Walker, J.T.A. 1903. The standardization of disinfectants. Journal of the Royal Sanitary Institute. 24: 424- 41.

Rosch, P., Harz, M., Schmitt, M., Peschke, K.D., Ronneberger, O., Burkhardt H, et al. 2005. Chemotaxonomic identification of single bacteria by micro-Raman spectroscopy: application to clean-room-relevant biological contaminations. Appl. Environ. Microbiology. 71(3):16261637.

Sanders, E.R. 2012. Aseptic Laboratory Techniques: Plating Methods. J. Vis. Experiments. 63:e3064.

Tavares, L.C., Vessoni, P.T.C. andAmaral, A.T. 1997.Synthesis and biological activity of nifuroxazide and analogs. Boll ChimFarmaceutico.3:244-249.

United States Pharmacopeia. USP 36 $<1116>$. Microbiological Evaluation of Clean Rooms and Other Controlled Environments. pp. 784-794.

\section{How to cite this article:}

Subhash Chand, Kallol Saha, Prakash Kumar Singh, Smriti Sri and Neeraj Malik. 2016. Determination of Minimum Inhibitory Concentration (MIC) of Routinely used Disinfectants against Microflora Isolated from Clean Rooms. Int.J.Curr.Microbiol.App.Sci. 5(1): 334-341 hittp://dx.doi.org/10.20546/ijcmas.2016.501.031 